\title{
Effect of integrated nutrient management on the growth and yield of senna in coastal sandy soil
}

\author{
R. SINGARAVEL, D. ELAYARAJAAND K.VISWANATHAN
}

Received : 11.03.2016; Revised : 18.04.2016; Accepted : 14.05 .2016

MEMBERS OF RESEARCH FORUM:

Corresponding author :

R. SINGARAVEL, Department of Soil Science and Agricultural Chemistry, Faculty of Agriculture, Annamalai University, Annamalai Nagar, CHIDAMBARAM (T.N.) INDIA Email: singar_vel@yahoo.co.in

\section{Co-authors :}

D. ELAYARAJA AND K.VISWANATHAN, Department of Soil Science and Agricultural Chemistry, Faculty of Agriculture, Annamalai University, Annamalai Nagar, CHIDAMBARAM (T.N.) INDIA

\section{Summary}

To increase the production of medicinal senna in sandy soils of coastal agro ecosystem, integrated nutrient management treatments involving inorganic fertilizers, organic manures namely FYM, vermicompost, humic acid and microbial consortium were evaluated. The intial soil was typic udipsamments and represented sandy texture and non-saline nature. In Completely Randomized Design, the following treatments were evaluated with three replications using senna as test crop. $\mathrm{T}_{1}$ - Absolute control, $\mathrm{T}_{2}-$ Recommended NPK, $\mathrm{T}_{3}$ FYM alone @ $12.5 \mathrm{tha}^{-1}, \mathrm{~T}_{4}$ - Vermicompost alone @ $4.0 \mathrm{tha}^{-1}, \mathrm{~T}_{5}-75 \% \mathrm{NPK}+\mathrm{FYM} @ 12.5$ $\mathrm{t} \mathrm{ha}^{-1}, \mathrm{~T}_{6}-50 \% \mathrm{NPK}+\mathrm{FYM} @ 12.5 \mathrm{t} \mathrm{ha}^{-1}, \mathrm{~T}_{7}-75 \% \mathrm{NPK}+$ vermicompost @ $4.0 \mathrm{tha}^{-1}, \mathrm{~T}_{8}-50$ $\% \mathrm{NPK}+$ vermicompost @ $4.0 \mathrm{t} \mathrm{ha}^{-1}, \mathrm{~T}_{9}-\mathrm{T}_{5}+\mathrm{ZnSO}_{4} @ 25 \mathrm{~kg} \mathrm{ha}^{-1}+$ humic acid foliar spray @ $0.3 \%, \mathrm{~T}_{10}-\mathrm{T}_{6}+\mathrm{ZnSO}_{4} @ 25 \mathrm{~kg} \mathrm{ha}^{-1}+$ humic acid foliar spray @ $0.3 \%, \mathrm{~T}_{11}-\mathrm{T}_{7}+\mathrm{ZnSO}_{4} @ 25$ $\mathrm{kg} \mathrm{ha}^{-1}+$ Humic acid foliar spray @ 0.3\%, $\mathrm{T}_{12}-\mathrm{T}_{8}+\mathrm{ZnSO}_{4} @ 25 \mathrm{~kg} \mathrm{ha}^{-1}+$ humic acid foliar spray@0.3\%. Bio inoculants, Azospirillum and phosphobacterium were applied to all the treatments excluding absolute control and recommended NPK. The results of the study indicated that the application of INM significantly improved the growth and yield of senna in coastal sandy soil. Among the treatments, application of $75 \%$ NPK fertilizer + vermicompost @ $4.0 \mathrm{t} \mathrm{ha}^{-1}+\mathrm{ZnSO}_{4} @ 25 \mathrm{~kg} \mathrm{ha}^{-1}$ with humic acid foliar spray ranked best in recording the higher growth character, leaf and pod yield of senna and available soil nutrients.

Key words : Senna, Integrated nutrient management, Sandy soil

How to cite this article : Singaravel, R., Elayaraja, D. and Viswanathan, K. (2016). Effect of integrated nutrient management on the growth and yield of senna in coastal sandy soil. Asian J. Soil Sci., 11 (1) : 187-190 : DOI : 10.15740/HAS/AJSS/11.1/187-190. 